\title{
Parasitic Lesions in Fish in the Federal District, Brazil
}

\author{
Jair Alves Ferreira Junior ${ }_{\mathbb{D}}^{1}$, Saulo Pereira Cardoso $\mathbb{D}^{2}$, Nathália Dela-Sávia da Fonseca ${ }_{\mathbb{D}}^{1}$ ', \\ Karla Alvarenga Nascimento ${ }^{1}$, Fábio Rodrigues ${ }^{3}{ }^{3}$, Gino Chaves da Rocha ${ }^{4}$, \\ Juliana Targino Silva Almeida e Macêdo ${ }^{1}{ }^{1} \&$ Pedro Miguel Ocampos Pedroso ${ }^{1}$
}

\begin{abstract}
Background: Brazil has a vast territory and favorable climatic conditions that allow the cultivation of freshwater fish. The intensification of the productive system can cause an imbalance in the aquatic environment as a result of poor water quality, nutritional deficiencies and infectious or parasitic diseases. The laboratory diagnosis and the determination of the prevalence of the main lesions, which occur in a certain region, help to guide towards the etiological diagnosis. This study aimed to describe the main parasitic lesions in fish in the routine at the Veterinary Pathology Laboratory of the Universidade de Brasília (UnB).

Material, Methods \& Results: All records of fish with parasitic lesions were recovered. Those cases in which there was an intralesional parasite and which presented lesions compatible with the parasite were included. The screening of ectoparasites was done by scraping the superficial mucus from the gills and skin. Organ sections were routinely processed for histopathologyand stained with hematoxylin-eosin (HE). In some records, parasitological identification was carried. The information was divided into the species of the affected fish, epidemiology of the outbreak (water quality, temperature, type of breeding), lesion distribution, etiology and macroscopic and microscopic changes. The resulting data was organized in absolute frequency and percentage. In this study, 22 cases were counted, between individual deaths and outbreaks, totaling 83 necropsied teleost fish. Inflammatory changes of parasitic origin were seen in 13/22 (59\%) of the cases had lesions of parasitic origin. Skin lesions and gills were the most relevant. Macroscopically, red areas or spots of hyperemia or hemorrhage on the body surface were the most prevalent findings. Under microscopy, proliferative gill inflammation was the most relevant diagnosis. Pscinoodinium pilullare (Dinoflagellida), Ichthyophthirius multifiliis (Ciliophora), and monogenetic worms (Monogenea) were the main parasites found. Trichodina sp. (Ciliophora), Ichtyobodo sp. (Kinetoplastida), Amoebas, and Chilodonella sp. (Ciliophora), were seen in fewer numbers. An unusual case suggestive of parasitism by Eustrongylides sp. (Nematoda), in a pirá-brasília (Simpsonichthys boitonei), specimen has been recorded.

Discussion: The diagnoses were based on epidemiology, anatomopathological and parasitological findings. The most frequent and significantly lethal lesion in the study was proliferative and / or hyperplastic branchitis. Proliferative branchitis with lamellar epithelial hyperplasia (LEH) is a response to some type of chemical or mechanical injury to the gill epithelium in order to protect the capillaries from further damage or microbial penetration. However, it also increases the diffusion distance between capillaries and the environment and, therefore, hinders breathing, excretory and osmoregulatory functions. Protozoan infections and monogenetic worms in general generated LEH and skin lesions of mechanical origin. Secondary bacterial infection, were observed in this parasitosis determining the cause of death of the fish. Its pathogenicity comes from the lesions caused by the colonization and histophagy of the epithelial surfaces, mainly gills and skin, causing epithelial proliferation, lamellar cell fusion, epithelial cell degeneration and necrosis forming several ulcers in the epithelium after the release of mature trophies. The pathogenesis of parasitism by Eustrongylides spp. is considerable when there is a large quantity of these larvae that can cause intestinal obstruction, rupture and compression of viscera, of greater importance in small fish. The main parasites of necropsied fish were protozoa and monogenetic worms, which mainly cause branquitis and dermatitis in varying grades.
\end{abstract}

Keywords: fish, proliferative branchitis, skin, parasites, pathology.

DOI: $10.22456 / 1679-9216.113606$

Accepted: 15 June 2021

Published: 22 July 2021

${ }^{1}$ Veterinary Pathology Laboratory \& 4Laboratory of Parasitology and Parasitic Diseases (LPDP), Universidade de Brasília (UnB), Brasília, DF, Brazil. ${ }^{2}$ Instituto Federal do Mato Grosso (IFMT), Barra do Garça, MT, Brazil. ${ }^{3}$ Empresa de Assistência Técnica e Extensão Rural do Distrito Federal Emater (EMATER-DF), Brasília. CORRESPONDENCE: P.M.O. Pedroso [pedrosovet@ yahoo.com.br]. Via L4 Norte s\n. Campus Darcy Ribeiro. CEP 70910970 Brasília, DF, Brazil. 


\section{INTRODUCTION}

Brazil has a vast territory and favorable climatic conditions that allow the cultivation of freshwater fish [11]. The intensification of the productive system can cause an imbalance in the aquatic environment as a result of poor water quality, nutritional deficiencies and infectious or parasitic diseases. They are often associated with poor management and the absence of prophylactic measures that trigger chronic stress in fish and, subsequently, immunosuppression [12]. Therefore, the laboratory diagnosis and the determination of the prevalence of the main lesions, which occur in a certain region, help to guide the pathologist towards the etiological diagnosis. The Veterinary Pathology Laboratory of the Universidade de Brasília (UnB), has made diagnoses of diseases in medium to small fish farms, in the Distrito Federal and Surroundings, in partnership with other government agencies. This study aimed to describe the main parasitic lesions in fish in the routine at the Veterinary Pathology Laboratory of the Universidade de Brasília.

\section{MATERIALS AND METHODS}

\section{Sampling}

All records of fish with parasitic lesions were recovered. Those cases in which there was an intralesional parasite and which presented lesions compatible with the parasite were included.

\section{Parasitology and pathology}

The screening of ectoparasites was done by scraping the superficial mucus from the gills and skin. The mucus obtained in the scrape was compressed between a slide and a coverslip and immediately observed under a standard optical microscope, according to Jerônimo et al. [5]. Organ sections were fixed in a $10 \%$ formalin solution, embedded in paraffin, cut into 5 - $\mu$ m-thick sections, and stained with hematoxylin-eosin (HE) ${ }^{1}$. In some records, parasitological identification was carried out by the Laboratory of Parasitology and Parasitic Diseases (LPDP-UnB). When the diagnosis was not made, at the species level of the parasite, its order, class or family was designated. The information was divided into the species of the affected fish, epidemiology of the outbreak (water quality, temperature, type of breeding), lesion distribution, etiology and macroscopic and microscopic changes.

\section{Statistical analysis}

The resulting data was organized in absolute frequency and percentage.

\section{RESULTS}

In the routine at the Veterinary Pathology Laboratory, 22 cases were counted, between individual deaths and outbreaks, totaling 83 necropsied teleost fish. All fish came from the Federal District, most of them (16/22 cases), from small producers or from subsistence farming. The species involved were tilápia-do-nilo (Oreochromis niloticus - 64.63\%), tambaqui (Colossoma macropomum - $14.63 \%$ ), pirapitinga (Piaractus brachypomus - $4.87 \%$ ), tambatinga (Colossoma macropomum x Piaractus brachypomus $-4.87 \%$ ), followed by pacu (Piaractus mesopotamicus), pirarucu (Arapaima gigas), painted (Pseudoplatystoma corruscans), carp (Cyprinus carpio) and pirá-brasília (Simpsonichthys boitonei), which totaled $10.93 \%$. Inflammatory changes of parasitic origin were seen in 13/22 (59\%) of the cases. Of these changes the sudden change in temperature or temperature below the ideal was recorded in 2/13 (15\%), outbreaks. Mortality rates ranged from 10 to $100 \%$ and the main complaints were of fish found dead, lethargic or with erratic swimming in $9 / 13$ (69\%); friction on the wall of the tanks in $1 / 13(8 \%)$; red areas of the skin or gills with increased mucus production in $11 / 13$ (85\%). The main morphological diagnosis was proliferative or mixed hyperplastic branchitis, with or without atrophy and fusion of secondary lamellae in 10/13 (77\%). The proliferative aspect was characterized by epithelial hyperplasia associated with the mixed infiltrate of lymphocytes, granulocytes and macrophages that expanded the primary and secondary lamellae, promoting their collapse (fusion).

The main parasites found were the protozoa Pscinoodinium pillulare (3/13), Ichthyophthirius multifiliis (2/13) and monogenetic worms (Monogenea) (7/13) [Table 1]. In all cases involving monogenetics, Trichodina spp. and Chilodonella spp. it was possible to observe and identify the parasite in the direct examination (Figure 1).

In one case was identified Dawestrema spp. (Monogenea), in a pirarucu. The protozoan Trichodina spp., was associated with four outbreaks, but with low infestations. In one of the cases of ichthyophytosis, associated with monogenetics in tambaqui, $10 \%$ mortality was registered. There was a complaint of lethargy and lack of appetite that evolved to the appearance of hemorrhagic areas associated with erosions and ulcers on the body surface, sometimes with muscle exposure and scales that loosened easily after manipulation. This lesion was attributed to secondary fungal and bacterial infections (Figure 2A). The diagnosis was 
based on the observation of the protozoan and transverse and longitudinal cuts of monogenetics fixed by hooks on the branchial lamellae (Figure 2B).

Similar findings were also observed in piscinoodiniasis and the drop in ambient temperature was recorded in $1 / 3$ of the cases. In another outbreak, mortality reached $22 \%$. A peculiar macroscopic characteristic was observed in one of the outbreaks in which the body surface and the gills were covered with brown lumps (Figure 2C). Microscopy showed an interlamellar space distended by oval trophies, a vacuolated eosinophilic cytoplasm containing rhizocysts, measuring about $30 \mu \mathrm{m}$ by $160 \mu \mathrm{m}$ (Figure 2D).

Mixed parasitism, causing or not causing injury, was observed in 4/13 of the cases (31\%). Among them, an outbreak of infection by amoebas and Chilodonella sp. (1/22). In this case, there was no parasitological or molecular identification of the amoeba, however it was identified as belonging to the phylum Amoebozoa based on the morphological characteristics in histopathology. Randomly, round, basophilic trophozoites, of vacuolated cytoplasm, irregularly rounded central nucleus were observed in the interlamellar space, measuring about $30 \mu \mathrm{m}$ suggestive of amoebae. These parasitic structures were associated with the proliferative branchial lesion, with atrophy, fusion of secondary lamellae and hyperplasia of chloride cells, assuming the trophozoites are the lesion's etiology. There was a case of Ichtyobodo sp. branchitis, when $90 \%$ of the carp in an aquarium died within a month. The carp showed red spots on the skin and small prominent lesions (Figure 2E). Clinically, they presented frictional movements against the bottom of the tank (itching), became apathetic and were found dead. In $25 \%$ of the fish, microscopically, on the surface and ends of the primary and secondary lamellae, there was moderate parasitism by piriform protozoa attached by thin rods (flagella), measuring approximately $6 \times 5 \mu \mathrm{m}$, characteristics consistent with Ichthyobodo sp. (Figure 2F). On the skin, it was possible to notice the surface of the epidermis covered by basophilic mucous material and a large quantity of Gram-negative bacillary bacteria (suggestive of Aeromonas spp.), erosions and edema.

There was also a case of parasitism accentuated by larvae of worms compatible with those nematodes, of the Dioctophimatidae family, in the visceral cavity of a pirá-brasília (Simpsonichthys boitonei), suggestive of Eustrongylides sp. The marked expansion of the fish's abdominal cavity culminated in the formation of a parasitic cyst with compression of the viscera and death. Microscopy revealed a focal cyst of a fibrous capsule, which occupied $50 \%$ of the visceral cavity, containing various transverse and longitudinal sections of pseudocelomatised nematodes, with thick, wavy integument, amber color, celomary musculature and large intestine, covered by columnar uninucleated cells.

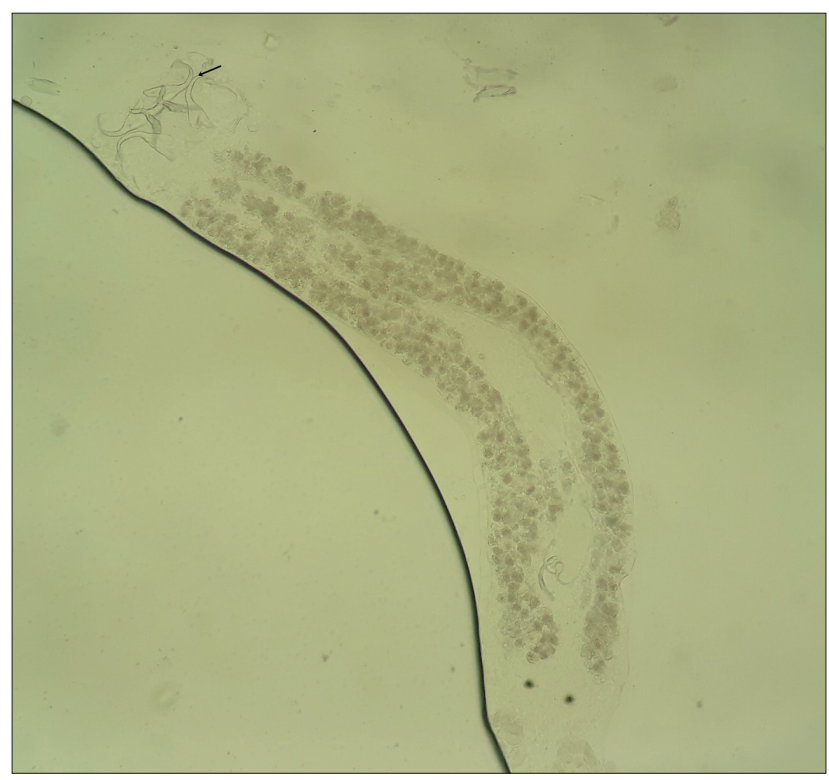

Figure 1. Monogenea parasitism in tilápia-do-nilo, skin scraping, direct examination. There is a monogenetic worm suggestive of gyrodactylid with hooks at its end (arrow) [obj.40x].

\section{DISCUSSION}

The diagnoses were based on epidemiology, anatomopathological and parasitological findings. The advancement of fish farming was noted as an alternative income, since most of the samples received came from small producers assisted by agencies such as the Empresa deAssistência Técnica e Extensão Rural do Distrito Federal (EMATER-DF), with emphasis on the creation of tilápiasdo-nilo. The most frequent and significantly lethal lesion in the study was proliferative and / or hyperplastic branchitis. Proliferative branchitis with lamellar epithelial hyperplasia (LEH) is a response to some type of chemical or mechanical injury to the gill epithelium in order to protect the capillaries from further damage or microbial penetration. However, it also increases the diffusion distance between capillaries and the environment and, therefore, hinders breathing, excretory and osmoregulatory functions [16]. This lesion can appear in infestations with protozoa or monogenetic worms in fish, due to its traumatic action on the epithelium causing the tissue reaction and pathogenesis $[9,15]$. Skin and gills were the main injured organs as they are the preferred location of the studied parasites [5]. 


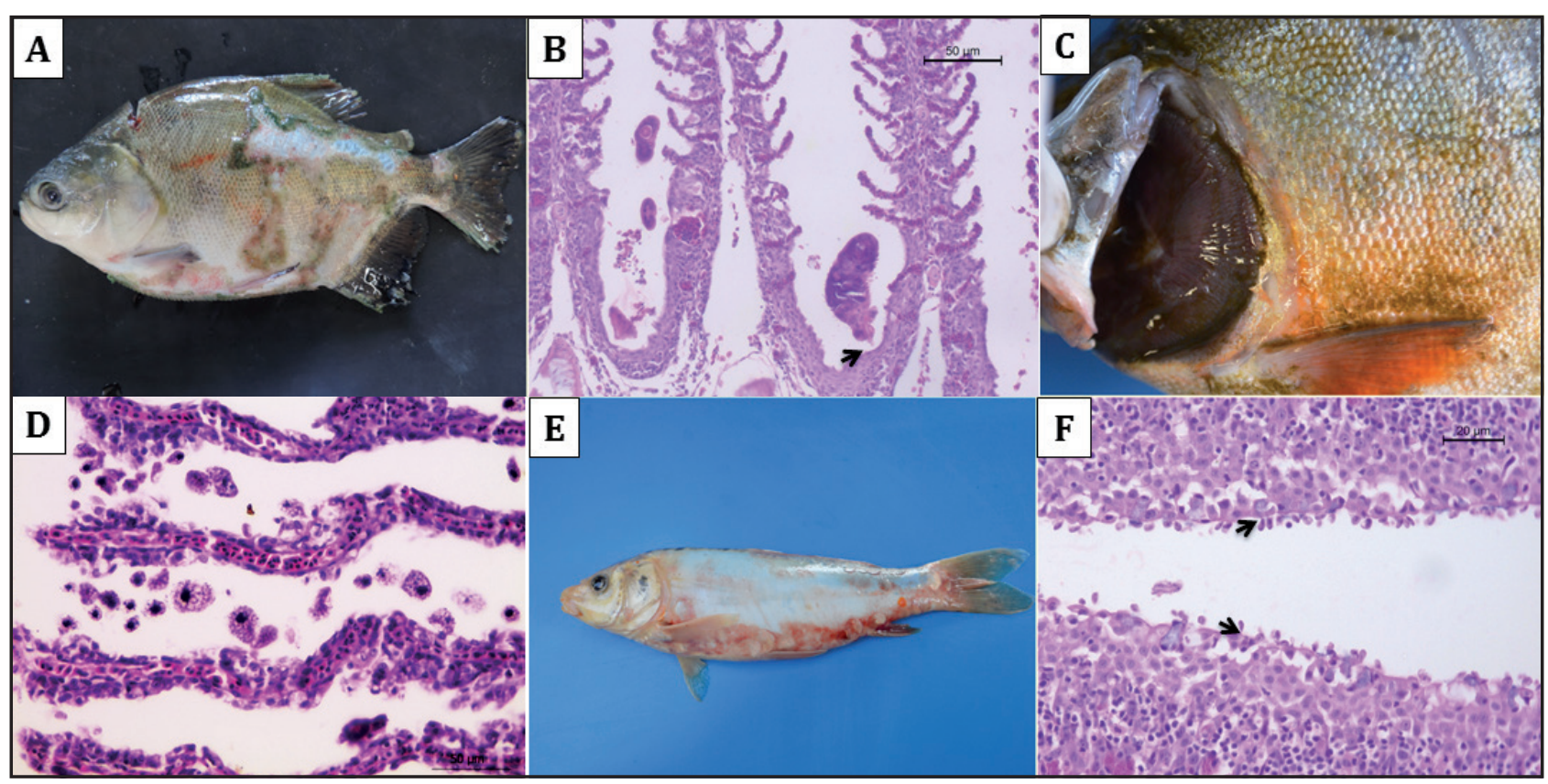

Figure 2. A- Outbreak of infection by Ichthyophthirius multifiliis and Dactylogyrus sp. in tambaqui (Colossoma macropomum). There are hemorrhagic areas associated with erosions and ulcers on the body surface, sometimes with muscle exposure. B- Infection by Dactylogyrus sp. in tambaqui. Note the cut of the parasite fixed by its hooks (haptor) on the gill lamellar surface (arrow) [HE; obj.20x]. C- Pscinoodiniasis in pirapitinga (Piaractus brachypomus). Note the body and gill surface with increased amount of yellow to green mucus and covered by brown lumps. D- Branchitis by Pscinoodinium pillullare. A large number of protozoan trophons can be seen in the interlamellar space with atrophy and fusion of the secondary branchial lamellae [HE; obj.40x]. E- Ichthiobodose in carp (Cyprinus carpio). There are red spots on the skin adjacent to the fins and small protruding mucous lesions. F- Ichthiobodose in carp (Cyprinus carpio). Note on the surface of the secondary piriform protozoan lamellae attached by thin rods (flagella) (arrow), measuring approximately 6 x5 $\mu \mathrm{m}$, consistent with Ichthyobodo spp. [HE; obj.40x].

Infestations by monogenetic worms were the most observed. Monogenetics (Monogenoidea), are helminths that are characterized by a fixation device with hooks that are located on the back of the body, the haptor. Lesions may vary, depending on the monogenetic species, and may cause hypersecretion of mucus, fusion of gill lamellae, which leads to death by asphyxiation. In addition, injuries to the integument caused by the haptor can favor secondary infection by bacteria and fungi [15]. Even in small amounts, monogenetics can promote an increase in the production of mucus and pruritus and large infestations indicate a decrease in the quality of breeding sites, such as overcrowding and water, such as high levels of ammonia, nitrite, organic pollution and low oxygen [10]. The monogenetic Dawestrema sp., was identified in one case. Despite its pathogenic potential, it is considered to be a specific host and commonly found in pirarucus in the Amazônia basin or in the Araguaia-Tocantins rivers $[8,14]$.

Ichthyophthirius multifiliis, which causes "white dots" disease, is a parasite of importance throughout the world and in the investigated outbreaks it has caused mortality rates of $10 \%$ to $30 \%$ in tanks with a high amount of organic matter and temperatures of $27^{\circ} \mathrm{C}$ in the afternoon period, factors that favored the outbreak. The coexistence of infected fish with non-infected ones and fishing tools, such as fishing nets and utensils, are means of transmission of I. multifiliis terontes. In addition, water temperatures above $24^{\circ} \mathrm{C}$ and below $28^{\circ} \mathrm{C}$, favor and accelerate the life cycle of the protozoan [9]. Marked proliferative branchial lesions and skin ulcers, with secondary bacterial infection, were observed in this parasitosis determining the cause of death of the fish. Its pathogenicity comes from the lesions caused by the colonization and histophagy of the epithelial surfaces, mainly gills and skin, causing epithelial proliferation, lamellar cell fusion, epithelial cell degeneration and necrosis forming several ulcers in the epithelium after the release of mature trophies [9].

The dinoflagellate parasite, $P$. pilullare, was responsible for $3 / 13$ of the registered cases. This protozoan has a worldwide distribution and is already known as one of the differential diagnoses of I. multifillis and as a trigger of outbreaks with high mortality in the Midwest, with epidemiology and known macro 
Table 1. List of LPV-UnB fish necropsy records with parasitic lesions divided by species and macroscopic and microscopic findings.

\begin{tabular}{|c|c|c|c|c|}
\hline ID & Species & Etiology & Macroscopy & Microscopy \\
\hline 1 & $\begin{array}{c}\text { Tambatinga and } \\
\text { Pirapitinga }\end{array}$ & Piscinoodinium pillulare $(+++)$ & Red dots on gill filaments & $\begin{array}{c}\text { Accentuated diffuse mixed necrotizing } \\
\text { proliferative branchitis }\end{array}$ \\
\hline $2 *$ & $\begin{array}{l}\text { Tilápia-do-nilo, } \\
\text { tambaqui and } \\
\text { Pirapitinga }\end{array}$ & $\begin{array}{l}\text { Pscinoodinium pillulare }(++) \\
\text { Trichodina } \mathrm{spp} .(+)\end{array}$ & $\begin{array}{l}\text { Multifocal pale and red areas } \\
\text { on the skin }\end{array}$ & $\begin{array}{l}\text { Moderate multifocal mixed proliferative } \\
\text { branchitis; } \\
\text { Skin without changes [3] }\end{array}$ \\
\hline 3 & $\begin{array}{l}\text { Pirapitinga and } \\
\text { Pintado }\end{array}$ & Piscinoodinium pillulare $(+++)$ & $\begin{array}{c}\text { Brown lumpy mucus on the } \\
\text { body and gill surface }\end{array}$ & $\begin{array}{l}\text { Diffuse mixed proliferative branchitis marked } \\
\text { with secondary lamella atrophy }\end{array}$ \\
\hline 4 & Tilápia-do-nilo & $\begin{array}{c}\text { Ichthyophthirius multifiliis }(+++) \\
\text { Trichodina } \text { spp. }(+) \\
\text { Monogenea }(+)\end{array}$ & $\begin{array}{l}\text { Irregular red areas on the skin } \\
\text { Pale gills }\end{array}$ & $\begin{array}{l}\text { Accentuated diffuse mixed hyperplastic } \\
\text { bronchitis; } \\
\text { Mild multifocal hyperplastic dermatitis }\end{array}$ \\
\hline 5 & Tambaqui & $\begin{array}{c}\text { Ichthyophthirius multifiliis }(+++) \\
\text { Monogenea }(+++) \\
\text { Trichodina }(+)\end{array}$ & $\begin{array}{l}\text { Pale gills } \\
\text { Skin ulcers covered by } \\
\text { greenish mucus }\end{array}$ & $\begin{array}{c}\text { Marked diffuse hyperplastic mixed bronchitis; } \\
\text { Heterophilic necrotizing dermatitis with } \\
\text { intralesional bacteria }\end{array}$ \\
\hline 6 & Tilápia-do-Nilo & Trichodina $(+)$ & $\begin{array}{l}\text { Darkened skin with } \\
\text { multifocal red areas }\end{array}$ & $\begin{array}{l}\text { Lymphoplasmocytic branchitis with atrophy and } \\
\text { fusion of secondary lamellae }\end{array}$ \\
\hline 7 & Pirarucu & Monogenea $(+++)$ & Without changes & Accentuated diffuse mixed proliferative branches \\
\hline 8 & Tilápia-do-nilo & Monogenea (++) & $\begin{array}{l}\text { Irregular red areas in the } \\
\text { operculum and adjacent to } \\
\text { the fins }\end{array}$ & $\begin{array}{l}\text { Mild multifocal lymphogranulocytic dermatites; } \\
\text { Moderate diffuse mixed proliferative branchitis. }\end{array}$ \\
\hline 9 & Tilápia-do-nilo & Monogenea (++) & Without changes & Moderate mixed proliferative branchitis. \\
\hline 10 & Pirarucu & Dawestrema spp. $(+++)$ & $\begin{array}{l}\text { Hyperemia with loss of } \\
\text { scales on the skin } \\
\text { Corneal opacity }\end{array}$ & $\begin{array}{l}\text { Moderate multifocal heterophilic and } \\
\text { macrophagic necrotizing branchitis. } \\
\text { Focal heterophilic ulcerative dermatitis. } \\
\text { Corneal ulcer and edema }\end{array}$ \\
\hline 11 & Tilápia-do-nilo & $\begin{array}{l}\text { Amoebas }(+++) \\
\text { Chilodonella spp. }(+) \\
\text { Monogenea }(+)\end{array}$ & $\begin{array}{l}\text { hite areas adjacent to the } \\
\text { operculum and hyperemia of } \\
\text { the dorsal fin }\end{array}$ & $\begin{array}{l}\text { Mixed proliferative branchitis with secondary } \\
\text { lamella atrophy and chloride cell hyperplasia }\end{array}$ \\
\hline 12 & Carp & Ichthyobodo spp. $(++)$ & $\begin{array}{l}\text { Depressed red and mucous } \\
\text { cutaneous areas in the ventro- } \\
\text { caudal region }\end{array}$ & $\begin{array}{l}\text { Dermatite mista difusa moderada. } \\
\text { Mixed proliferative branchitis }\end{array}$ \\
\hline 13 & Pirá-brasília & $\begin{array}{l}\text { Nematode: Dioctophymatidae } \\
\qquad(+++)\end{array}$ & $\begin{array}{l}\text { Marked increase in volume in } \\
\text { the celomatic cavity }\end{array}$ & $\begin{array}{l}\text { Parasitic cyst containing nematodes with } \\
\text { pseudocelomates with coelomyarian musculature } \\
\text { and large intestine }\end{array}$ \\
\hline
\end{tabular}

+ Ligth parasitism; ++ Moderate parasitism; +++ Accentuate parasitism. *This outbreak was already reported [3].

and microscopic changes $[9,13]$. Brownish-colored lumps on the body surface and in the gills are consistent with the coloration that the parasite presents in the direct parasitological examination [9], which macroscopically assists in the presumptive diagnosis. Like Sant'Ana et al. [13], the etiopathogenesis in the cases was determined by observing the protozoan trophons in the interlamellar space promoting proliferative branchitis with atrophy and fusion of branchial villi.

Ichthyobodo spp., was associated with an outbreak where $90 \%$ of the carp in an aquarium died. Ichthiobodose, also called costiosis, is capable of causing high mortality rates even without evident pathology and great economic losses in cultivation situations $[7,10]$. As in this case, epithelial hyperplasia, ulcers and dermatitis were found in the affected fish [7]. In the case evaluated, skin lesions were more proliferative and hemorrhagic, due to friction against the aquarium wall. Increased mucus production can give fish a bluish hue [10]. The histological diagnosis used consisted of identifying the fixed form of piriform flagellate trophozoites of Ichthyobodo spp. Although difficult to be detected, in heavy infestations, they can be located by concentrating up and down, in greater 
magnification, on the edge of the branchial epithelium forming palisades [10].

A presumptive case of amoeba bleach was investigated. Amoeba trophozoites were the only intralesional organisms observed in the gills and, therefore, considered the main cause of the injury. The identification of Amoebozoa is complex and is based on the morphology of trophozoites. They usually consist of the observation of microorganisms with vacuolated cytoplasm and endosome, important for histological identification [1]. However, frequently, this identification cannot be made only by optical microscopy, when molecular methods must be used [2]. The main differential diagnosis for our case was amoebic branchial disease, in which there are hyperplastic lesions that result in lamellar fusion and cavity formation. However, cavity formation was not observed and molecular analysis was not performed, which excluded this diagnosis. In this context, other amphibious amoebas that parasitize gills are included, such as Neoparamoeba (Paramoeba), Thecamoeba and Trinema [1].

Parasitism accentuated by larvae of nematodes from the family Dioctophimatidae, suggestive of $E u$ strongylides sp., was recorded in a small fish (Simpsonichthys boitonei). It is believed that the small size of the celomatic cavity in relation to the parasites was the trigger for the death of the fish. The pathogenesis of parasitism by Eustrongylides spp. is considerable when there is a large quantity of these larvae that can cause intestinal obstruction, rupture and compres- sion of viscera, of greater importance in small fish $[11,12]$. Controversially, the larvae of Eustrongylides sp. are encysted in the musculature, mesentery and gastrointestinal tract of fish and piscivorous birds, not necessarily causing the death of the host [2]. In Brazil, this parasite is more described in traíras (Hoplias marabaricus) with an emphasis on its zoonotic potential when man becomes an accidental host by eating raw or undercooked fish [6]. Histopathology was able to confirm the order of the parasite with help in the etiology. Characteristics such as pseudoceloma, large intestine with uninucleated cells, coelomyarian musculature and thick integument are found in ascarids [4].

\section{CONCLUSION}

The main parasites of necropsied fish were protozoa and monogenetic worms, which mainly cause branquitis and dermatitis in varying grades. The etiological diagnosis could be based on epidemiology and anatomopathological findings related to its pathogenesis.

\section{MANUFACTURER \\ ${ }^{1}$ WCOR Corantes. São Paulo, SP, Brazil.}

Acknowledgments. To pathologists, teachers, former residents and technicians of LPV-UnB, veterinarians and producers who collaborated with the diagnoses and information.

Declaration of interest. The authors report no conflicts of interest. The authors alone are responsible for the content and writing of the paper.

\section{REFERENCES}

1 Bruno D.W., Nowak B. \& Elliott D.G. 2006. Guide to the identification of fish protozoan and metazoan parasites in stained tissue sections. Diseases of Aquatic Organisms. 70: 1-36.

2 Eiras J.C. 2013. Amebozoa. In: Pavanelli G.C., Takemoto R.M. \& Eiras J.C. (Eds). Parasitologia de Peixes de Água Doce do Brasil. Maringá: EDUEM, pp.195-198.

3 Ferreira Júnior J.A., Leonardo A.S., Azevedo J.P.M.V.B., Rodrigues F.R., Nascimento K.A., Macêdo J.T.A. \& Pedroso P.M.O. 2018. Surto de infecção por Pscinoodinium pillulare e Trichodina spp. em tambaquis (Colossoma macropomum), pirapitingas (Piaractus brachypomus) e tilápias (Oreochromis niloticus) no Distrito Federal. Acta Scientiae Veterinaria. 46(suppl 1): 293. 5p.

4 Gardiner C.H. \& Poynton S.L. 2006. Ascarids. In: An Atlas of Metazoan Parasites in Animal Tissues. Washington: Registry of Veterinary Pathology of Armed Forces Institute of Pathology, pp.20-22.

5 Jerônimo G.T., Tavares-Dias M., Martins M.L. \& Ishikawa M.M. 2012. Coleta de Parasitos em Peixes de Cultivo. Brasília: Embrapa, 38p.

6 Kuraiem B.P., Knoff M., Telleria E.L., Fonseca M.C.G., Machado L.S., Cunha N.C., Nascimento E.R., Fontenelle G., Gomes D.C. \& São Clemente S.C. 2020. Eustrongylides sp. (Nematoda, Dioctophymatoidea) parasitizing Hoplias malabaricus (Actinopterygii: Erythrinidae) collected from the state of Rio de Janeiro, Brazil. Brazilian Journal of Veterinary Parasitology. 29(1): e014519. DOI: 10.1590/S1984-29612019094 
7 Marchiori N.C. \& Martins M.L. 2013. Flagellata. In: Pavanelli G.C., Takemoto R.M. \& Eiras J.C. (Eds). Parasitologia de Peixes de Água Doce do Brasil. Maringá: EDUEM, pp.201-216.

8 Marinho R.G.B., Tavares-Dias M., Dias-Grigório M.K.R., Neves L.R., Yoshioka E.T.O., Boijink C.D.L. \& Takemoto R.M. 2013. Helminthes and protozoan of farmed pirarucu (Arapaima gigas) in eastern Amazon and hostparasite relationship. Arquivo Brasileiro de Medicina Veterinária e Zootecnia. 65(4): 1192-1202. DOI: 10.1590/S010209352013000400035

9 Martins M.L., Cardoso L., Marchiori N. \& Pádua S.B.2015. Protozoan infections in farmed fish from Brazil: diagnosis and pathogenesis. Brazilian Journal Veterinary Parasitology. 24(1): 1-20. DOI: 10.1590/S1984-29612015013

10 Noga E.J. 2010. Nematode infection. In: Fish Disease: Diagnosis and Treatment. 2nd edn. Ames: Wiley-Blackwell, pp.215-222.

11 Pavanelli G.C., Eiras J.C. \& Takemoto R.M. 2008. Manejo. In: Doenças de Peixes: Profilaxia, Diagnóstico e Tratamento. 3.ed. Maringá: EDUEM, pp.1-50.

12 Portz L., Antonucci A.M., Ueda B.H., Dotta G., Guidelli G., Roumbedakis K., Martins M.L., Carniel M.K. \& Tavechio W.L.G. 2013. Parasitos de Peixes de Cultivo e Ornamentais. In: Pavanelli G.C., Takemoto R.M. \& Eiras J.C. (Eds). Parasitologia de Peixes de Água Doce do Brasil. Maringá: EDUEM, pp.85-88.

13 Sant'Ana F.J.F., Oliveira S.L., Rabelo R.E., Vulcani V.A.S., Silva S.M.G. \& Ferreira Júnior J.A. 2012. Surtos de infecção por Piscinoodinium pillulare e Henneguya spp. em pacus (Piaractus mesopotamicus) criados intensivamente no Sudoeste de Goiás. Pesquisa Veterinária Brasileira. 32(2): 121-125. DOI: doi.org/10.1590/S0100-736X2012000200005

14 Santos S.M.C., Ceccarelli P.S. \& Luque J.L. 2008. Helminth parasites of pirarucu, Arapaima gigas (Schinz, 1822) (Osteoglossiformes: Arapaimidae) from Araguaia River, State of Mato Grosso. Revista Brasileira de Parasitologia Veterinária. 17(3): 171-173.

15 Takemoto R.M., Luque J.L., Bellay S., Longhini C.E. \& Graça R.J. 2013. Monogenea. In: Pavanelli G.C., Takemoto R.M. \& Eiras J.C. (Eds). Parasitologia de Peixes de Água Doce do Brasil. Maringá: EDUEM, pp.273-283.

16 Wolf J.C., Baumgartner W.A., Blazer V.S., Camus A.C., Engelhardt J.A., Fournie J.W., Frasca Jr. S., Groman D.B., Kent M.L., Khoo L.H., Law J.M., Lombardini E.D., Ruehl-Fehlert C., Segner H.E., Smith S.A., Spitsbergen J.M., Weber K. \& Wolfe M.J. 2015. Nonlesions, misdiagnoses, missed diagnoses, and other interpretive challenges in fish histopathology studies: a guide for investigators, authors, reviewers, and readers. Toxicology Pathology. 43(3): 297-325. DOI: 10.1177/0192623314540229 